\title{
Age-Related Changes of Urine Calcium Excretion after Extracorporeal Shock Wave Lithotripsy due to Artificial Renal Calcium Leakage
}

\author{
Sven Oehlschläger O.W. Hakenberg Michael Froehner M.P. Wirth \\ Department of Urology, Technical University, Dresden, Germany
}

Key Words

Renal stones · Lithotripsy $\cdot$ Renal function $\cdot$ Calcium

\begin{abstract}
Introduction: Extracorporeal shock wave lithotripsy (ESWL) is the standard stone treatment. Increased excretion of tubular enzymes and hypercalciuria has been reported after ESWL. We investigated the importance of renally induced hypercalciuria after ESWL. Material and Methods: 30 calcium oxalate stoneformers ( 23 men, 7 women), mean age 53.3 (range 30-71) years, were evaluated prospectively. Plasma calcium and creatinine concentrations and 8-hour overnight urine were measured before ESWL and on the 1st and 2nd days after ESWL. To estimate the changes of tubular reabsorption, the calcium/creatinine clearance ratios were calculated. Results: Hypercalciuria ( $>5 \mathrm{mmol} / 24 \mathrm{~h}$ ) was seen in $5 / 30(16.7 \%)$ before, in $12 / 30(40.0 \%)$ on day 1 and in $13 / 30$ (43.3\%) on day 2 after ESWL. The mean plasma levels of calcium were significantly decreased from $2.36 \mathrm{mmol} / \mathrm{l}$ before to $2.28 \mathrm{mmol} / \mathrm{l}$ on day 2 after ESWL $(\mathrm{p}<0.01)$. The mean calcium/creatinine clearance ratio was significantly increased from 0.012 before to 0.019 after ESWL $(p<0.01)$. Before and on day 2 after ESWL, the calcium/creatinine clearance ratio was significantly correlated with the age of the patients $(r=$ $0.33, p<0.04$ ). Conclusion: Our data show an age-related significantly increased urine calcium excretion after ESWL possibly due to decreased tubular calcium reabsorption.
\end{abstract}

Copyright $\odot 2008$ S. Karger AG, Basel

\section{KARGER}

Fax +4161306 1234

E-Mail karger@karger.ch

www.karger.com
C) 2008 S. Karger AG, Basel

0042-1138/08/0812-0206\$24.50/0

Accessible online at:

www.karger.com/uin

\section{Objectives}

Extracorporeal shock wave lithotripsy (ESWL) alone is the treatment of choice for approximately $90-95 \%$ of all stone-forming patients, or in combination with other procedures in the remaining stone patients. Depending on the size, location and composition of the stones and the anatomic abnormalities of the collecting system, the presence of residual stone material after ESWL is common $[1,2]$. An increase in stone formation and the growth of residual fragments after lithotripsy due to urine hypersaturation has been reported [3].

Changes in renal function after ESWL have also been documented, with increased tubular enzymes, glomerular protein excretion in urine and hypercalciuria seen from 1 up to 5 days after primary ESWL [4-7]. The tubular damage may be explained by ischemic anoxia of tubular cells after lithotripsy and induced bleeding of the renal parenchyma, followed by generation of free radicals and lipid peroxidation resulting in toxicity to tubular cells [8].

The tubular epithelium plays an important role in renal calcium clearance. After the glomerular filtration of about $60 \%$ of plasma calcium, only $1-2 \%$ of the filtrated calcium is eliminated with the urine because of a highly specific tubular reabsorption process [9]. The calcium/ creatinine clearance ratio $(\mathrm{Ca} / \mathrm{CrCl}$ ratio) strongly correlates with the tubular function of calcium reabsorption. $\mathrm{Ca} / \mathrm{CrCl}$ ratios of 0.01 are associated with normal renal 
Table 1. Stone size, stone location, applied shock waves and stone analysis of the treated patients

\begin{tabular}{ll}
\hline Mean stone size & $8.9 \times 7.4( \pm 4.8) \mathrm{mm}$ \\
Caliceal stones & 20 patients \\
Renal pelvic stones & 10 patients \\
Mean applied shock waves & $2,681( \pm 849)$ waves \\
\hline
\end{tabular}

tubular function [10]. Thus, tubular shock wave-induced damage might correlate with changes of renal clearance of calcium. We investigated the clinical importance of renally induced hypercalciuria in calcium-oxalate stoneformers after primary ESWL.

\section{Materials and Methods}

In a prospective study, 30 calcium-oxalate-forming patients (23 men, 7 women) were evaluated. The mean age of the patients was $53.3 \pm 12.4$ years. All patients had normal creatinine clearance, normal intravenous pyelograms and normal serum values of parathyroid hormones. The urine was sterile in all patients. The ESWL was performed with the lithotriptors MFL 5000 and Siemens Multiline. Stone size, stone location, applied shock waves and stone analysis of the treated patients are given in table 1. Urine samples from 8-hour overnight collection (10 p.m. to 6 a.m.) were measured before ESWL and on day 1 (up to $18 \mathrm{~h}$ after ESWL) and day 2 (up to $42 \mathrm{~h}$ after ESWL). The measurements from the urine samples were extrapolated to a 24-hour value. Fluid intake was not restricted. Patients received the normal hospital diet and recorded their daily dietary intake (table 2).

Means were compared by Wilcoxon's test and correlation were calculated by Pearson's correlation coefficient.

\section{Results}

Hypercalciuria ( $>5 \mathrm{mmol} / 24 \mathrm{~h}$ ) was seen in $5 / 30$ (16.7\%) patients before ESWL, in $12 / 30(40.0 \%)$ on day 1 (up to $18 \mathrm{~h}$ after ESWL) and in 13/30 (43.3\%) on day 2 (up to $42 \mathrm{~h}$ after ESWL) (table 3 ). There were stable creatinine clearance values after ESWL in comparison to the values before (table 4). The mean values of calculated 24 -hour urine calcium excretion increased significantly from 3.57 $\mathrm{mmol} / 24 \mathrm{~h}$ before ESWL to $5.09 \pm 3.0 \mathrm{mmol} / 24 \mathrm{~h}$ on day $1(\mathrm{p}<0.01)$ and to $5.23 \mathrm{mmol} / 24 \mathrm{~h}$ on day 2 after ESWL ( $\mathrm{p}<0.01$; table 3$)$. Mean plasma levels of calcium were significantly decreased from $2.36 \mathrm{mmol} / \mathrm{l}$ before ESWL to $2.28 \mathrm{mmol} / \mathrm{l}$ on day 2 after ESWL ( $\mathrm{p}<0.01)$. The mean calcium/creatinine clearance ratio was significantly increased from 0.012 before ESWL to 0.019 after ESWL
Table 2. Daily dietary intake of the patients with the code of diet

\begin{tabular}{|c|c|c|c|}
\hline Patient No. & $\begin{array}{l}\text { Day before } \\
\text { ESWL }\end{array}$ & $\begin{array}{l}\text { Day of } \\
\text { ESWL }\end{array}$ & $\begin{array}{l}\text { 1st day after } \\
\text { ESWL }\end{array}$ \\
\hline 1 & 1 & 3 & 5 \\
\hline 2 & 1 & 2 & 5 \\
\hline 3 & 4 & 2 & 4 \\
\hline 4 & 4 & 3 & 5 \\
\hline 5 & 1 & 3 & 5 \\
\hline 6 & 1 & 1 & 5 \\
\hline 7 & 4 & 3 & 5 \\
\hline 8 & 4 & 3 & 5 \\
\hline 9 & 1 & 3 & 5 \\
\hline 10 & 1 & 3 & 5 \\
\hline 11 & 5 & 3 & 5 \\
\hline 12 & 1 & 2 & 5 \\
\hline 13 & 1 & 2 & 5 \\
\hline 14 & 1 & 3 & 5 \\
\hline 15 & 1 & 2 & 5 \\
\hline 16 & 2 & 1 & 1 \\
\hline 17 & 1 & 2 & 5 \\
\hline 18 & 4 & 2 & 1 \\
\hline 19 & 5 & 3 & 1 \\
\hline 20 & 1 & 2 & 2 \\
\hline 21 & 5 & 6 & 5 \\
\hline 22 & 3 & 5 & 1 \\
\hline 23 & 5 & 6 & 5 \\
\hline 24 & 5 & 6 & 5 \\
\hline 25 & 4 & 6 & 5 \\
\hline 26 & 6 & 3 & 5 \\
\hline 27 & 5 & 5 & 6 \\
\hline 28 & 1 & 3 & 5 \\
\hline 29 & 1 & 3 & 1 \\
\hline 30 & 1 & 3 & 1 \\
\hline
\end{tabular}

The diet codes following are given in the order breakfast/ lunch/dinner. 1 = Continental breakfast/soup/soup; 2 = fasting/ fasting/fasting; 3 = fasting/fasting/dinner; 4 = continental breakfast/lunch/soup; 5 = continental breakfast/lunch/dinner; 6 = fasting/lunch/dinner.

$(\mathrm{p}<0.01$; table 4$)$. A significant correlation of the calci$\mathrm{um} /$ creatinine clearance ratio with age was seen before ESWL $(\mathrm{r}=0.33, \mathrm{p}<0.037)$ and on day 2 after treatment $(\mathrm{r}=0.33, \mathrm{p}<0.040)$ (fig. 1).

\section{Discussion}

ESWL, due to the high efficiency and low morbidity rate of the HM3 lithotriptor, became the treatment of choice for most renal stones after 1980 [11]. With the high number of residual fragments after primary ESWL, 
Table 3. Plasma calcium and calculated 24-hour calcium urine excretion (mean $\pm \mathrm{SD})$

\begin{tabular}{lll}
\hline & $\begin{array}{l}\text { Plasma calcium } \\
\mathrm{mmol} / \mathrm{l}\end{array}$ & $\begin{array}{l}\text { Calcium in urine } \\
\mathrm{mmol} / 24 \mathrm{~h}\end{array}$ \\
\hline Before ESWL & $2.36 \pm 0.12$ & $3.57 \pm 2.3$ \\
1st day (18 h) after ESWL & $2.32 \pm 0.10$ & $5.09 \pm 3.0^{* *}$ \\
2nd day (42 h) after ESWL & $2.28 \pm 0.10^{*}$ & $5.23 \pm 3.3^{* *}$ \\
\hline
\end{tabular}

Wilcoxon's test comparing the values before and after ESWL. ${ }^{*} \mathrm{p}<0.05,{ }^{* *} \mathrm{p}<0.01$.

Fig. 1. Scatter plot with correlation between the age of the patients and the calcium/creatinine clearance ration $42 \mathrm{~h}$ after ESWL ( $\mathrm{r}=$ 0.33 ; $\mathrm{p}<0.04$; Persons' correlation coefficient).

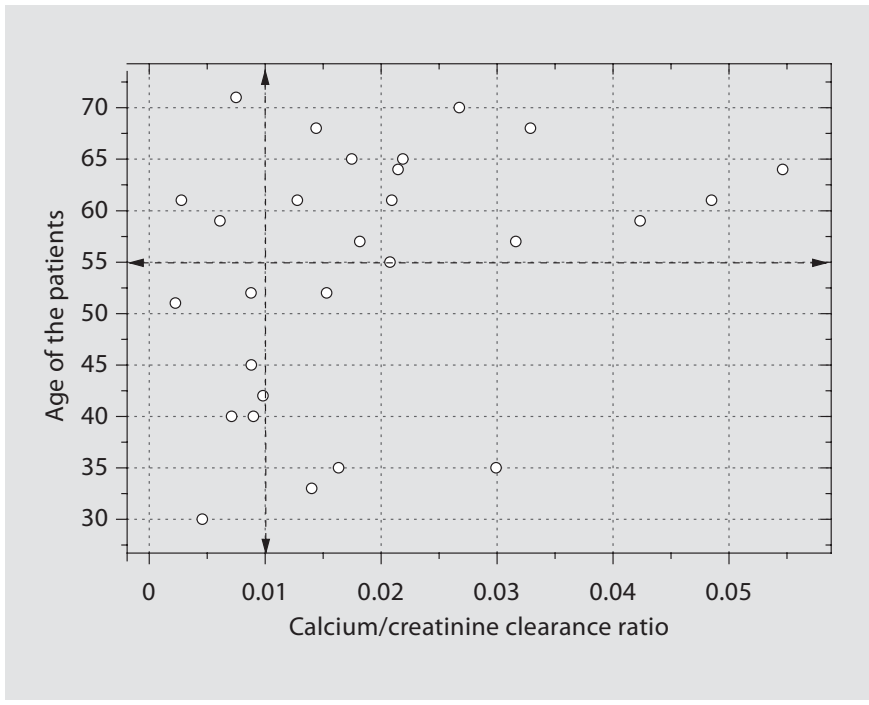

Table 4. Urine volume, creatinine clearance and calcium/creatinine clearance ratio (mean \pm SD)

\begin{tabular}{llll}
\hline & $\begin{array}{l}\text { Urine volume } \\
\mathrm{ml}\end{array}$ & $\begin{array}{l}\text { Creatinine clearance } \\
\mathrm{ml} / \mathrm{min}\end{array}$ & $\begin{array}{l}\text { Calcium/creatinine } \\
\text { clearance ratio }\end{array}$ \\
\hline Before ESWL & $579 \pm 372$ & $77.4 \pm 23.6$ & $0.012 \pm 0.007$ \\
1st day (18 h) after ESWL & $974 \pm 573^{*}$ & $78.3 \pm 30.7$ & $0.019 \pm 0.011^{*}$ \\
2nd (42 h) after ESWL & $815 \pm 350^{*}$ & $79.8 \pm 30.0$ & $0.019 \pm 0.014^{*}$ \\
\hline
\end{tabular}

Wilcoxon's test comparing the values before and after ESWL. ${ }^{*} \mathrm{p}<0.01$.

further treatment or other measures are needed to render the patients stone free [3,12-14]. Retreatment rates after primary ESWL are significantly correlated with stone burden and location. Stone-free rates are about 63, 73 and $71 \%$ for lower, middle and upper caliceal stones [15].

In our study, early significant changes in the 8-hour overnight urine collection after ESWL were measurable under conditions of a nonstandardized diet. The number of calcium-oxalate stoneformers with pathological calcium urine excretion increased significantly from $5 / 30$ before ESWL to 13/30 $42 \mathrm{~h}$ after ESWL in the study group. With a stable creatinine clearance after ESWL, the calcium/creatinine clearance ratios were significantly increased indicating decreased tubular reabsorption. The calcium plasma levels were also significantly decreased over the investigated period. Hypercalciuria due to higher oral calcium intake therefore appears to be unlikely. Thus, it seems that tubular dysfunction after ESWL leads to hypercalciuria because of a decreased tubular reabsorption of the filtrated calcium.

Several studies have demonstrated that an oral citrate treatment after ESWL can decrease the regrowth of residual fragments. These studies showed a $75 \%$ reduction in size in residual fragments and a $28.5 \%$ reduction in stone recurrences under treatment with oral citrate $[16$, 17]. Oral citrate elevates urinary $\mathrm{pH}$ values, reduces calcium excretion, inhibits the urine calcium binding capacity and increases the urinary citrate excretion. Therefore, calcium oxalate stone forming patients who can be expected to undergo repeated lithotripsy for a large stone mass might benefit from early metaphylaxis with oral citrate treatment in order to reduce the early regrowth of residual fragments related to ESWL-induced hypercalciuria.

The tubular effects as expressed by hypercalciuria were more pronounced in older than in younger patients. In our study, patients over 55 years of age had a high- 
er risk for post-lithotripsy hypercalciuria. Concerning ESWL-induced tubular damage, Strohmaier et al. [18] demonstrated that calcium antagonists (e.g. nifedipine) produce a protective effect. In conclusion to our data, patients over 55 years seem to have more benefit from protective agents to reduce the tubular damage after ESWL. Our findings might also be of relevance for the timing of ESWL retreatment as these should be done after the restoration of normal tubular function $[4,16]$.

\section{Conclusions}

Our data show a significantly increased urinary calcium excretion, with potential implications for early metaphylaxis in calcium oxalate stone-forming patients after primary ESWL. Furthermore, age-dependent damage of tubular renal function was seen, which might be of relevance for the timing of ESWL retreatment and the use of protective tubular agents for patients over 55 years.

\section{References}

1 Beck EM, Riehle RA Jr: The fate of residual fragments after extracorporeal shock wave lithotripsy monotherapy of infection stones. J Urol 1991;145:6-9.

2 Oehlschläger S, Albrecht S, Hakenberg OW, Schrodter S, Froehner M, Manseck A, Wirth MP: Early changes of oxalate and calcium urine excretion in those with calcium oxalate stone formation after extracorporeal shock wave lithotripsy. Urology 2003;62:1720.

3 Streem SB, Yost A, Mascha E: Clinical implications of clinically insignificant store fragments after extracorporeal shock wave lithotripsy. J Urol 1996;155:1186-1190.

4 Abrahams C, Lipson S, Ross L: Pathologic changes in the kidneys and other organs of dogs undergoing extracorporeal shock wave lithotripsy with a tubless lithotripter. J Urol 1988;140:391-394.

5 Karlsen SJ, Berg KJ: Acute changes in kidney function following extracorporeal shock wave lithotripsy for renal stones. Br J Urol 1991;67:241-245.

6 Rassweiler J, Kohrmann KU, Back W, Frohner S, Raab M, Weber A: Experimental basis of shockwave-induced renal trauma in the model of the canine kidney. World J Urol 1993; 11:43-53.
7 Rutz-Danielczak A, Pupek-Musialik D, Raszeja-Wanic B: Effects of extracorporeal shock wave lithotripsy on renal function in patients with kidney stone disease. Nephron 1998;79:162-166.

8 Biri H, Ozturk HS, Buyukkocak S, Kacmaz M, Cimen MY, Unal D, Birey M, Bozkirli I, Durak I: Antioxidant defense potential of rabbit renal tissues after ESWL: protective effects of antioxidant vitamins. Nephron 1998;79:181-185.

9 Sutton RAL: Renal filtration and reabsorption of calcium; in Coe FL, Favus MJ, Pak CYC, Parks JH, Preminger GM (eds): Kidney Stones: Medical and Surgical Management. Philadelphia, Lippincott Raven, 1996, pp 223-238

10 Pfeilschifter J, Schatz H: Differential diagnosis of hypercalcemia in adults. Med Klin 2000;95:143-150.

11 Riehle RA Jr, Naslund EB, Fair W, Vaughan ED Jr: Impact of shockwave lithotripsy on upper urinary tract calculi. Urology 1986;28: 261-269.

12 Caramia G, Di Gregorio L, Tarantino ML, Galuffo A, Iacolino R, Caramia M: Uric acid, phosphate and oxalate stones: treatment and prophylaxis. Urol Int 2004;72(suppl 1):2428.

13 Meschi T, Schianchi T, Ridolo E, Adorni G, Allegri F, Guerra A, Novarini A, Borghi L: Body weight, diet and water intake in preventing stone disease. Urol Int 2004;72(suppl 1):29-33.
14 Zanetti G, Seveso M, Montanari E, Guarneri A, Del Nero A, Nespoli R, Trinchieri A: Renal stone fragments following shock wave lithotripsy. J Urol 1997;158:352-355.

15 Obek C, Onal B, Kantay K, Kalkan M, Yalcin V, Oner A, Solok V, Tansu N: The efficacy of extracorporeal shock wave lithotripsy for isolated lower pole calculi compared with isolated middle and upper caliceal calculi. J Urol 2001;166:2081-2084.

16 Cicerello E, Merlo F, Gambaro G, Maccatrozzo L, Fandella A, Baggio B, Anselmo G: Effect of alkaline citrate therapy on clearance of residual renal stone fragments after extracorporeal shock wave lithotripsy in sterile calcium and infection nephrolithiasis patients. J Urol 1994;151:5-9.

17 Soygur T, Akbay A, Kupeli S: Effect of potassium citrate therapy on stone recurrence and residual fragments after shockwave lithotripsy in lower caliceal calcium oxalate urolithiasis: a randomized controlled trial. J Endourol 2000;16:149-152.

18 Strohmaier WL, Koch J, Balk N, Wilbert DM, Bichler KH: Limitation of shock-waveinduced renal tubular dysfunction by nifedipine. Eur Urol 1994;25:99-104. 